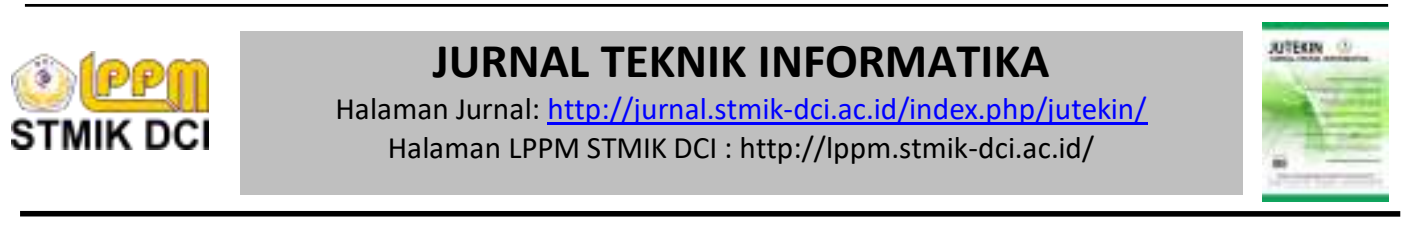

\title{
SISTEM PENDUKUNG PENGAMBILAN KEPUTUSAN PENERIMAAN CALON KARYAWAN DENGAN MENGGUNAKAN METODE TOPSIS (STUDI KASUS : PT. BANK MANDIRI CABANG TASIKMALAYA)
}

\author{
Andri Sukmaindrayana ${ }^{1}$, Aneu Yulianeu ${ }^{2}$ \\ Prodi Teknik Informatika STMIK DCI ,Email : andri@stmik-dci.ac.id ${ }^{1}$ \\ Prodi Manajemen Informatika STMIK DCI, Email : aneu@stmik-dci.ac.id²
}

\begin{abstract}
ABSTRAK
Dalam proses seleksi calon karyawan, seringkali keputusan yang diambil bersifat subjektif. Hal ini terjadi karena tidak ada metode standar yang sistematis untuk menilai kelayakan calon karyawan. Untuk memecahkan permasalahan tersebut perlu dibuat suatu sistem pendukung keputusan yang dapat membantu perusahaan.

Sistem Pendukung Keputusan merupakan suatu pendekatan (atau metodologi) untuk mendukung pengambilan keputusan. SPK menggunakan Sistem Informasi Berbasis Komputer yang fleksibel, interaktif, dan dapat diadaptasi, yang dikembangkan untuk mendukung solusi untuk masalah manajemen yang spesifik yang tidak terstruktur. SPK menggunakan data, memberikan antarmuka pengguna yang mudah, dan dapat menggabungkan pemikiran pengambil keputusan.

Topsis diperkenalkan pertama kali oleh Yoon dan Hwang tahun 1981 untuk digunakan sebagai salah satu metode dalam memecahkan masalah multikriteria (sachdeva, 2009). Topsis memberikan sebuah solusidari sejumlah arternatif yang mungkin dengan cara membandingkan setiap alternatif dengan altrnatif terbaik dan alternatif terburuk yang ada diantara alternatif-alternatif masalah. Metode ini melakukan jarak untuk melakukan perbandingan tersebut. Topsis telah digunakan dalam banyak aplikasi termasuk investasi keuangan perbandingan performasi dari perusaahaan.
\end{abstract}

Kata Kunci : Karyawan, Sistem Pendukung Keputusan, Topsis

\section{PENDAHULUAN}

Semakin pesatnya perkembangan teknologi dalam dunia bisnis sekarang, pengambilan suatu keputusan merupakan faktor penting dalam menentukan keputusan yang harus diambil dalam menghadapi persaingan dunia bisnis.
Perusahaan sebagai organisasi, membutuhkan sistem komputerisasi dalam mengumpulkan, menyimpan, dan memproses data untuk menghasilkan informasi yang dapat membantu perusahaan dalam melakukan 
perencanaan strategi dan pengambilan suatu keputusan secara efektif.

PT. Bank Mandiri Cabang Tasikmalaya merupakan perusahaan yang bergerak dalam bidang perbankan. Salah satu faktor terpenting pada perusahaan ini yaitu karyawan. Karyawan yang berkualitas akan menghasilkan kinerja dan prestasi yang baik untuk perusahaan. Human Resources Department (HRD) perlu melakukan proses seleksi calon karyawan karena merupakan bagian yang terpenting untuk mendapatkan calon karyawan yang berkualitas dan berkompeten. Perusahaan harus berhatihati dalam pengambilan keputusan saat melakukan selaksi calon karyawan untuk menilai kemampuan dan psikologis calon karyawan.

Dalam proses seleksi calon karyawan, seringkali keputusan yang diambil bersifat subjektif. Hal ini terjadi karena tidak ada metode standar yang sistematis untuk menilai kelayakan calon karyawan. Untuk memecahkan permasalahan tersebut perlu dibuat suatu sistem pendukung keputusan yang dapat membantu perusahaan.

\section{LANDASAN TEORI}

\subsection{Pengertian Karyawan}

Karyawan adalah orang penjual jasa (pikiran dan tenaga) dan mendapatkan kompensasi (upah) yang besarnya telah ditetapkan terlebih dahulu.

\subsection{Pengertian Seleksi}

Menurut T. Hani Handoko (1996:146): seleksi adalah serangkaian langkah kegiatan yang digunakan untuk memutuskan apakah pelamar diterima atau tidak diterima oleh perusahaan tersebut.
Menurut Malayu S.P Hasibuan ( 2002:47): seleksi adalah suatu kegiatan pemilihan dan penentuan pelamar yang diterima atau ditolak untuk menjadi karyawan perusahaan.

Dari definisi diatas dapat ditarik kesimpulan bahwa seleksi pegawai adalah memperoleh karyawan yang paling tepat dalam kualitas maupun kuantitas dari calon-calon yang akan ditariknya. Dan dapat ditambahkan kembali bahwa seleksi sangat berperan bila ternyata para karyawan berprestasi baik sesuai dengan yang diharapkan. Oleh karena itu seleksi merupakan hal yang penting untuk dilaksanakan.

\subsection{Profil PT. Bank Mandiri}

Bank Mandiri merupakan salah satu Bank yang terbesar yang ada di Indonesia saat ini, yang memiliki nasabah yang banyak. Bank Mandiri berdiri pada tanggal 2 Oktober 1998 sebagai bagian dari Program Restrukturisasi perbankan yang di laksanakan olen Pemerintah Indonesia. Pada bulan Juli 1999, 4 Bank milik Pemerintah yaitu Bank Bumi Daya, Bank Dagang Negara, Bank Ekspor Impor Indonesia dan Bank Pembangunan Indonesia, bergabung menjadi Bank Mandiri. Keempat Bank tersebut telah turut membentuk riwayat perkembangan dunia perbankan di Indonesia. Kini, Bank Mandiri menjadi penerus tradisi layanan jasa perbankan dan keuangan yang telah berpengalaman selama lebih dari 140 tahun. Masing-masing dari empat Bank bergabung memainkan peranan yang penting dala pembangunan ekonomi bersama Bank Mandiri.

Bank Mandiri terbentuk dari sekumpulan Bank yang mempunyai reputasi yang baik di masanya, dengan adanya merger ini menjadikan Bank 
Mandiri tumbuh besar dan memiliki banyak nasabah.

\subsection{Sistem Pendukung Keputusan}

Sistem Pendukung Keputusan merupakan suatu pendekatan (atau metodologi) untuk mendukung pengambilan keputusan. SPK menggunakan Sistem Informasi Berbasis Komputer yang fleksibel, interaktif, dan dapat diadaptasi, yang dikembangkan untuk mendukung solusi untuk masalah manajemen yang spesifik yang tidak terstruktur.

\subsection{Metode Technique For Order Preference by Similarity to Ideal Solution (TOPSIS)}

Topsis diperkenalkan pertama kali oleh Yoon dan Hwang tahun 1981 untuk digunakan sebagai salah satu metode dalam memecahkan masalah multikriteria (sachdeva, 2009). Topsis memberikan sebuah solusidari sejumlah arternatif yang mungkin dengan cara membandingkan setiap alternatif dengan altrnatif terbaik dan alternatif terburuk yang ada diantara alternatif-alternatif masalah.

\subsection{Tahap-Tahap Metode Topsis}

Berikut ini adalah tahap-tahap metode Topsis :

1. Membuat matriks keputusan yang ternormalisasi.

2. Membuat matriks keputusan yang ternormalisasi terbobot.

3. Menentukan matriks solusi ideal positif dan matriks solusi ideal negatif.

4. Menentukan jarak antara nilai setiap alternatif dengan matriks solusi ideal positif dan negatif.

5. Menentukan niali preferensi untuk setiap alternatif.

\subsection{Borland Delphi 7}

Borland Delphi 7 merupakan bahasa pemrograman berbasis Windows. Delphi 7 dapat membantu untuk membuat berbagai macam aplikasi yang berjalan di sistem operasi Windows, mulai dari sebuah program sederhana sampai dengan program yang berbasiskan client/server atau jaringan.

\subsection{MySQL}

MySQL adalah sebuah program database server yang mampu menerima dan mengirimkan datanya dengan sangat cepat, multi user serta menggunakan perintah standar SQL ( Structured Query Language).

\subsection{Data Flow Diagram ( DFD)}

Yaitu gambaran jaringan dari sebuah sistem yang bersifat manual, otomatis atau gabungan keduanya.

\subsection{Basis Data}

Basis data (database) adalah suatu kumpulan data yang disusun dalam bentuk tabel-tabel yang saling berkaitan maupun berdiri sendiri dan disimpan secara bersama-sama pada suatu media.

\section{ANALISIS MASALAH}

\subsection{Tahapan Analisis}

\subsubsection{Identifikasi Penyebab Masalahan}

Dalam identifikasi penyebab masalah yang dihadapi saat ini adalah belum tersedianya suatu aplikasi khusus yang berbasis komputer untuk mendukung dalam proses penerimaan calong karyawan sehingga diharapkan dapat memuat perhitungan untuk dengan sebuah metode dengan cepat.

\subsubsection{Identifikasi Titik keputusan}


Hasil akhir yang diharapkan dari aplikasi yang penyusun buat adalah menghasilkan nilai-nilai yang mewakili satu nilai persyaratan masing-masing calon karyawan yang akan digunakan sebagai bahan penilaian penerimaan karyawan baru pada studi kasus di PT. Bank Mandiri Tasikmalaya.

\subsection{Analisis Data Dengan Metode Topsis}

\subsubsection{Kebutuhan Data}

1. Data Calon Karyawan, digunakan sebagai data alternatif untuk masing-masing calon karyawan yang akan diseleksi.

2. Data Kriteria, merupakan nama kriteria seleksi dan memberikan nilai bobot.

Data Kriteria Seleksi meliputi aspek antara lain :
a. $\quad \mathrm{CO1}=$ Keahlian;
b. $\mathrm{CO2}=$ Pengalaman;
c. $\quad \mathrm{CO}=$ Kesehatan Fisik;
d. $\mathrm{CO} 4=$ Pendidikan;
e. $\mathrm{CO5}=$ Umur;
f. $\quad \mathrm{C06}=$ Kerjasama;
g. $\quad \mathrm{CO}=$ Kejujuran;
h. $\quad \mathrm{C08}=$ Inisiatif dan Kreatif;
i. $\quad \mathrm{CO9}=$ Kedisiplinan.

3. Rating Kecocokan

Rating kecocokan setiap alternatif pada setiap kriteria, dinilai dengan 1 sampai 5 dengan ketentuan:

1 = Sangat Buruk;

2 = Buruk;

3 = Cukup;

4 = Baik;

5 = Sangat Baik.

4. Bobot Preferensi

Sedangkan tingkat kepentinga yang nantinya akan dijadikan bobot preferensi setiap kriteia juga dinilai dengan 1 sampai 5, dengan ketentuan:

1 = Sangat Rendah;
2 = Rendah;

3 = Cukup;

4 = Tinggi;

5 = Sangat Tinggi.

\subsubsection{Langkah-Langkah Metode Topsis}

Berikut ini adalah mengenai penilaian rating kecocokan untuk tiap Kriteria untuk masing-masing alternatif calon karyawan beserta bobot preferensi.

\section{Tabel 3.1}

Tabel Penilaian Rating Kecocokan

\begin{tabular}{|l|l|l|l|l|l|l|l|l|l|}
\hline \multirow{2}{*}{$\begin{array}{l}\text { Alterna } \\
\text { tif }\end{array}$} & \multicolumn{10}{|c|}{ Kriteria } \\
\cline { 2 - 11 } & 0 & 0 & 0 & 0 & C & C & C & C & C \\
& 1 & 2 & 3 & 4 & 5 & 6 & 7 & 8 & 9 \\
\hline A01 & 3 & 5 & 4 & 2 & 3 & 1 & 2 & 4 & 4 \\
\hline A02 & 4 & 4 & 4 & 1 & 2 & 1 & 2 & 4 & 3 \\
\hline A03 & 2 & 4 & 4 & 3 & 1 & 3 & 3 & 2 & 2 \\
\hline A04 & 3 & 3 & 2 & 4 & 4 & 4 & 1 & 2 & 1 \\
\hline A05 & 3 & 2 & 2 & 2 & 4 & 2 & 4 & 3 & 4 \\
\hline A06 & 2 & 4 & 3 & 2 & 2 & 3 & 4 & 1 & 3 \\
\hline A07 & 1 & 5 & 1 & 2 & 3 & 3 & 2 & 5 & 3 \\
\hline A08 & 2 & 1 & 5 & 1 & 1 & 1 & 3 & 1 & 3 \\
\hline
\end{tabular}

Matrik keputusan yang dibentuk dari tabel kecocokan adalah sebagai berikut :

$$
X=\mid \begin{array}{lllllllll}
3 & 5 & 4 & 2 & 3 & 1 & 2 & 4 & 4 \\
4 & 4 & 4 & 1 & 2 & 1 & 2 & 4 & 3 \\
2 & 4 & 4 & 3 & 1 & 3 & 3 & 2 & 2 \\
3 & 3 & 2 & 4 & 4 & 4 & 1 & 2 & 1 \\
3 & 2 & 2 & 2 & 4 & 2 & 4 & 3 & 4 \\
2 & 4 & 3 & 2 & 2 & 3 & 4 & 1 & 3 \\
1 & 5 & 1 & 2 & 3 & 3 & 2 & 5 & 3 \\
2 & 1 & 5 & 1 & 1 & 1 & 3 & 1 & 3
\end{array}
$$


Untuk menyelesaikan masalah di atas dengan metode Topsis, akan dilakukan sesuai dengan langkah-langkah sebagai berikut :

1. Langkah Pertama, Normalisasi Matrik Keputusan.

$$
\begin{aligned}
& r_{11}=\frac{x_{11}}{\sqrt{\sum_{i=1}^{m} x_{i 1}^{2}}}= \\
& \frac{3}{\sqrt{3^{2}+4^{2}+2^{2}+3^{2}+3^{2}+2^{2}+1^{2}+2^{2}}}=\frac{3}{7,48}= \\
& 0,40 \\
& r_{12}=\frac{x_{12}}{\sqrt{\sum_{i=1}^{m} x_{i 2}^{2}}}= \\
& \frac{5}{\sqrt{5^{2}+4^{2}+4^{2}+3^{2}+2^{2}+4^{2}+5^{2}+1^{2}}}=\frac{5}{10,58}= \\
& 0,47
\end{aligned}
$$

dan seterusnya sampai dengan :

$$
\begin{aligned}
& r_{89}=\frac{x_{89}}{\sqrt{\sum_{i=1}^{m} x_{i 9}^{2}}} \\
& =\frac{3}{\sqrt{4^{2}+3^{2}+2^{2}+1^{2}+4^{2}+3^{2}+3^{2}+3^{2}}} \\
& =\frac{5}{8,54}=0,35
\end{aligned}
$$

Dari perhitungan di atas diperoleh matrik

$\mathrm{R}=\left|\begin{array}{rrrrrrrrr}0, & 0, & 0, & 0, & 0, & 0, & 0, & 0, & 0, \\ 40 & 47 & 42 & 30 & 39 & 14 & 25 & 46 & 47 \\ 0, & 0, & 0, & 0, & 0, & 0, & 0, & 0, & 0, \\ 53 & 38 & 42 & 15 & 26 & 14 & 25 & 46 & 35 \\ 0, & 0, & 0, & 0, & 0, & 0, & 0, & 0, & 0, \\ 27 & 38 & 42 & 46 & 13 & 42 & 38 & 23 & 23 \\ 0, & 0, & 0, & 0, & 0, & 0, & 0, & 0, & 0, \\ 40 & 28 & 21 & 61 & 52 & 57 & 13 & 23 & 12 \\ 0, & 0, & 0, & 0, & 0, & 0, & 0, & 0, & 0, \\ 40 & 19 & 21 & 30 & 52 & 28 & 50 & 34 & 47 \\ 0, & 0, & 0, & 0, & 0, & 0, & 0, & 0, & 0, \\ 27 & 38 & 31 & 30 & 26 & 42 & 50 & 11 & 35 \\ 0, & 0, & 0, & 0, & 0, & 0, & 0, & 0, & 0, \\ 13 & 47 & 10 & 30 & 39 & 42 & 25 & 57 & 35 \\ 0, & 0, & 0, & 0, & 0, & 0, & 0, & 0, & 0, \\ 27 & 09 & 52 & 15 & 13 & 14 & 38 & 11 & 35\end{array}\right|$

2. Langkah Kedua, Pembobotan Matrik Normalisasi. $V=R W$

$$
\begin{array}{|rrrrrrrrr}
0, & 0, & 0,4 & 0, & 0,3 & 0, & 0,2 & 0, & 0,4 \\
40 & 47 & 2 & 30 & 9 & 14 & 5 & 46 & 7 \\
& & & & & & & & \\
0, & 0, & 0,4 & 0, & 0,2 & 0, & 0,2 & 0, & 0,3 \\
53 & 38 & 2 & 15 & 6 & 14 & 5 & 46 & 5 \\
& & & & & & & & \\
0, & 0, & 0,4 & 0, & 0,1 & 0, & 0,3 & 0, & 0,2 \\
27 & 38 & 2 & 46 & 3 & 42 & 8 & 23 & 3 \\
& & & & & & & & \\
0, & 0, & 0,2 & 0, & 0,5 & 0, & 0,1 & 0, & 0,1 \\
40 & 28 & 1 & 61 & 2 & 57 & 3 & 23 & 2 \\
& & & & & & & & \\
0, & 0, & 0,2 & 0, & 0,5 & 0, & 0,5 & 0, & 0,4 \\
40 & 19 & 1 & 30 & 2 & 28 & 0 & 34 & 7 \\
& & & & & & & & \\
0, & 0, & 0,3 & 0, & 0,2 & 0, & 0,5 & 0, & 0,3 \\
27 & 38 & 1 & 30 & 6 & 42 & 0 & 11 & 5 \\
& & & & & & & & \\
0, & 0, & 0,1 & 0, & 0,3 & 0, & 0,2 & 0, & 0,3 \\
13 & 47 & 0 & 30 & 9 & 42 & 5 & 57 & 5 \\
& & & & & & & & \\
0, & 0, & 0,5 & 0, & 0,1 & 0, & 0,3 & 0, & 0,3 \\
27 & 09 & 2 & 15 & 3 & 14 & 8 & 11 & 5 \\
& & & & & & & &
\end{array}
$$

$\times\left|\begin{array}{lllllllll}5 & 0 & 0 & 0 & 0 & 0 & 0 & 0 & 0 \\ 0 & 2 & 0 & 0 & 0 & 0 & 0 & 0 & 0 \\ 0 & 0 & 3 & 0 & 0 & 0 & 0 & 0 & 0 \\ 0 & 0 & 0 & 4 & 0 & 0 & 0 & 0 & 0 \\ 0 & 0 & 0 & 0 & 1 & 0 & 0 & 0 & 0 \\ 0 & 0 & 0 & 0 & 0 & 4 & 0 & 0 & 0 \\ 0 & 0 & 0 & 0 & 0 & 0 & 5 & 0 & 0 \\ 0 & 0 & 0 & 0 & 0 & 0 & 0 & 3 & 0 \\ 0 & 0 & 0 & 0 & 0 & 0 & 0 & 0 & 4\end{array}\right|$

3. Langkah Ketiga, Menentukan Solusi Ideal.

a. Solusi Ideal Positif

$$
\begin{aligned}
& \mathrm{y} 1^{+}= \\
& \{2,00 ; 2,67 ; 1,34 ; 2,00 ; 2,00 ; 1,34 ; 0,67 ; 1,34\} \\
& =2,67 \\
& \mathrm{y} 2^{+}= \\
& \{0,94 ; 0,76 ; 0,76 ; 0,57 ; 0,38 ; 0,76 ; 0,94 ; 0,19\} \\
& =0,94 \\
& \text { dan seterusnya sampai dengan : }
\end{aligned}
$$




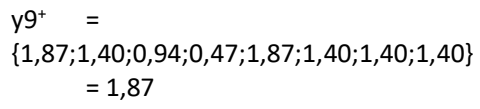

Sehingga diperoleh :

$\mathrm{A}^{+}=$

$\{2,67 ; 0,94 ; 1,56 ; 2,44 ; 0,52 ; 2,88 ; 2,50,1,71 ; 1,87\}$

b. Solusi Idea Negatif

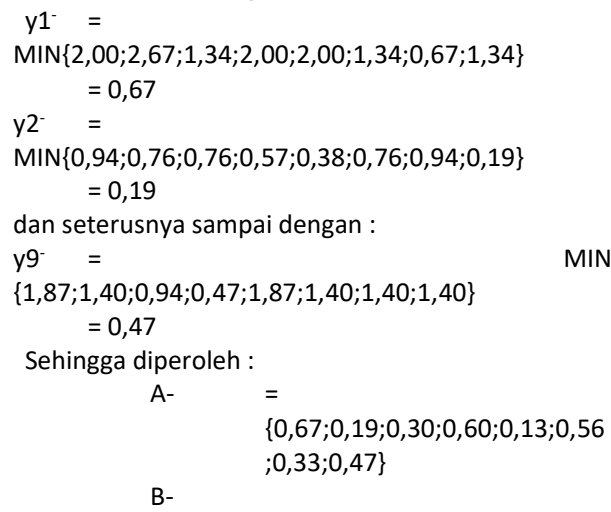

4. Langkah Keempat, Menghitung Jarak Nilai Terhadap Solusi Ideal.

a. Menghitung Jarak Nilai Terhadap Solusi Ideal Positif

$D 1^{+}$

$=\sqrt{(2,00-2,67)^{2}+(0,94-0,94)^{2}+\cdots+(1,87-1,87)^{2}}$

$D 2^{+}$

$=\sqrt{(2,67-2,67)^{2}+(0,76-0,94)^{2}+\cdots+(1,40-1,87)^{2}}$
$=2,90$

dan seterusnya sampai dengan :

$D 8^{+}$

$=\sqrt{(1,34-2,67)^{2}+(0,19-0,94)^{2}+\cdots+(0,19-1,40)^{2}}$
$=3,36$

Sehingga diperoleh matrik Jarak Nilai Terhadap Solusi Ideal Positif adalah:

Tabel 3.2

Matrik Jarak Nilai Terhadap Solusi Ideal

\begin{tabular}{|c|c|}
\multicolumn{2}{c}{ Positif } \\
\hline$D 1^{+}$ & 2,59 \\
\hline$D 2^{+}$ & 2,90 \\
\hline$D 3^{+}$ & 2,24 \\
\hline$D 4^{+}$ & 2,80 \\
\hline$D 5^{+}$ & 2,23 \\
\hline$D 6^{+}$ & 2,48 \\
\hline$D 7^{+}$ & 3,06 \\
\hline
\end{tabular}

\begin{tabular}{|l|l|}
\hline $\mathrm{D}^{+}$ & 3,36 \\
\hline
\end{tabular}

b. Menghitung Jarak Nilai Terhadap Solusi Ideal Negatif

$D 1^{-}$

$$
\begin{aligned}
& =\sqrt{(2,00-0,67)^{2}+(0,94-0,19)^{2}+\cdots+(1,87-0,47)^{2}} \\
& =3,13 \\
& =\sqrt{(2,67-0,67)^{2}+(0,76-0,19)^{2}+\cdots+(1,40-0,47)^{2}} \\
& =4,36 \\
& \text { dan seterusnya sampai dengan : } \\
& =\sqrt{(1,34-0,67)^{2}+(0,19-0,19)^{2}+\cdots+(0,19-0,47)^{2}} \\
& =2,43
\end{aligned}
$$

Sehingga diperoleh matrik Jarak Nilai Terhadap Solusi Ideal Negatif adalah :

Tabel 3.3

Matrik Jarak Nilai Terhadap Solusi Ideal

Negatif

\begin{tabular}{|c|c|}
\hline $\mathrm{D}^{-}$ & 3,13 \\
\hline $\mathrm{D}^{-}$ & 4,36 \\
\hline $\mathrm{D}^{-}$ & 2,76 \\
\hline $\mathrm{D}^{-}$ & 4,86 \\
\hline $\mathrm{D}^{-}$ & 4,40 \\
\hline $\mathrm{D}^{-}$ & 3,83 \\
\hline $\mathrm{D}^{-}$ & 2,55 \\
\hline $\mathrm{D}^{-}$ & 2,43 \\
\hline
\end{tabular}

5. Langkah Kelima, Menghitung Jarak Kedekatan Terhadap Solusi Ideal

$$
\begin{aligned}
& \mathrm{A} 01=\frac{D 1^{-}}{D 1^{-}+D 1^{+}}=\frac{3,13}{3,13+2,59}=0,55 \\
& \mathrm{~A} 02=\frac{D 2^{-}}{D 2^{-}+D 2^{+}}=\frac{4,36}{4,36+2,90}=0,60
\end{aligned}
$$

dan seterusnya sampai dengan :

$$
\mathrm{A} 08=\frac{D 8^{-}}{D 8^{-}+D 8^{+}}=\frac{2,43}{2,43+3,36}=0,42
$$

Sehingga diperoleh Jarak Kedekatan Terhadap Solusi Ideal adalah sebagai berikut : 
Tabel 3.4

Jarak Kedekatan Terhadap Solusi Ideal

\begin{tabular}{|l|c|}
\hline $\begin{array}{l}\text { Kode } \\
\text { Alternatif }\end{array}$ & $\begin{array}{l}\text { Jarak } \\
\text { Terhadap Solusi Ideal }\end{array}$ \\
\hline A01 & 0,55 \\
\hline A02 & 0,60 \\
\hline A03 & 0,55 \\
\hline A04 & 0,63 \\
\hline A05 & 0,66 \\
\hline A06 & 0,61 \\
\hline A07 & 0,45 \\
\hline A08 & 0,42 \\
\hline
\end{tabular}

Jika diurutkan berdasarkan jarak terdekat terhdap solusi ideal adalah sebagai berikut :

Tabel 3.5

Jarak terdekat terhdap solusi ideal

\begin{tabular}{|l|l|c|}
\hline No & $\begin{array}{l}\text { Kode } \\
\text { Alternatif }\end{array}$ & $\begin{array}{l}\text { Jarak } \\
\text { Terhadap Solusi Ideal }\end{array}$ \\
\hline 1 & A08 & 0,42 \\
\hline 2 & A07 & 0,45 \\
\hline 3 & A01 & 0,55 \\
\hline 4 & A03 & 0,55 \\
\hline 5 & A02 & 0,60 \\
\hline 6 & A06 & 0,61 \\
\hline 7 & A04 & 0,63 \\
\hline 8 & A05 & 0,66 \\
\hline
\end{tabular}

Jadi, dari permasalahan analisa kasus untuk menentukan 3 besar dari 8 orang calon karyawan yang diterima adalah calon karyawan yang memiliki kode alternatif A08, A07 dan A01.

\section{PERANCANGAN SISTEM}

\subsection{Diagram Konteks}

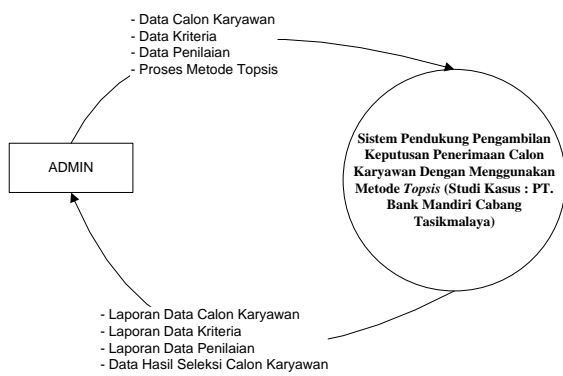

Gambar 4.1

Diagram Konteks

\subsection{DFD Level 1 dari Diagram Konteks}

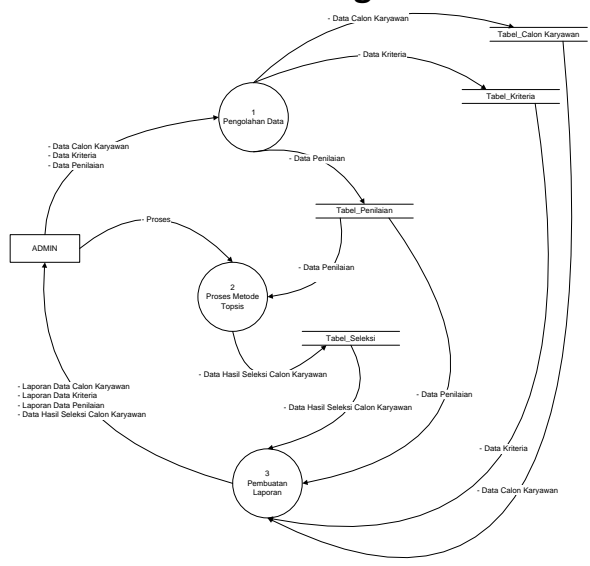

Gambar 4.2

DFD Level 1

\subsection{Rancangan Entity Relationship Diagram (ERD)}

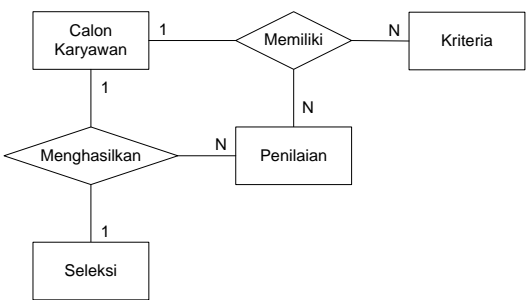

Gambar 4.3

ERD 
V. IMPLEMENTASI

\subsection{Form Menu Utama}

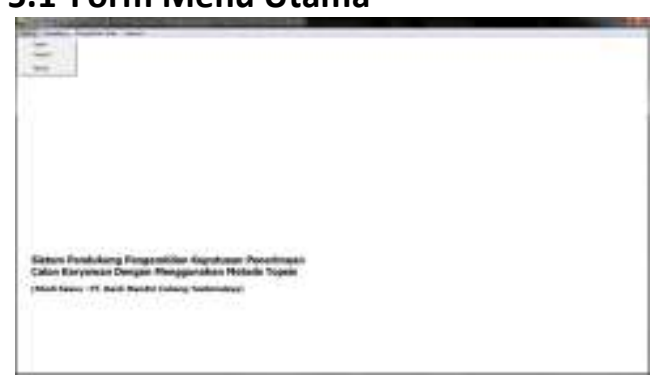

Gambar 5.1

Form Menu Utama

\subsection{Form Data Calon Karyawan}

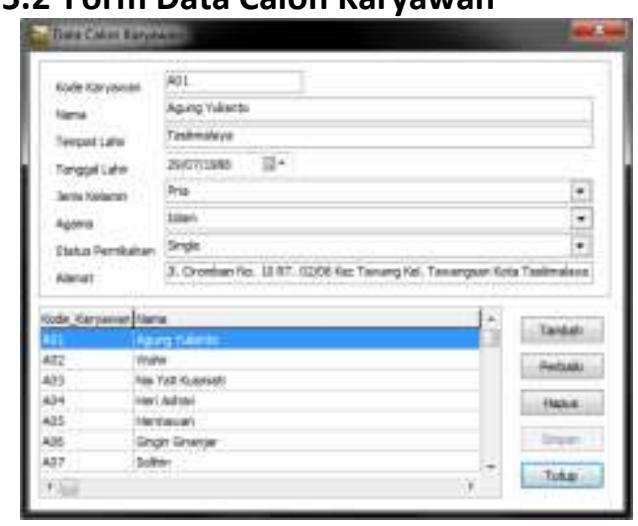

Gambar 5.2

Form Data Calon Karyawan

\subsection{Form Data Kriteria}

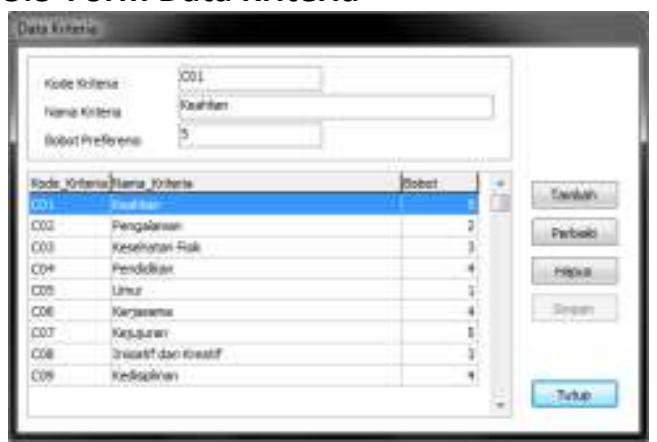

Gambar 5.3

Form Data Kriteria

\subsection{Form Data Penilaian}

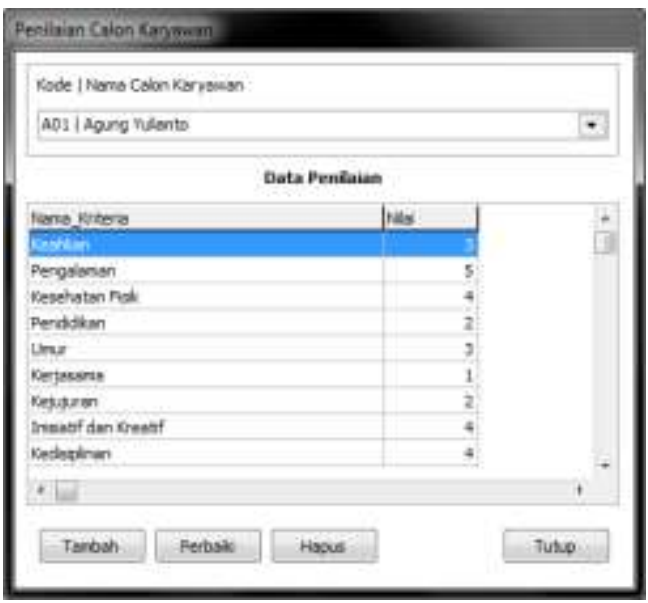

Gambar 5.4

Form Data Penilaian

\subsection{Form Proses Metode Topsis} [Penilaian]

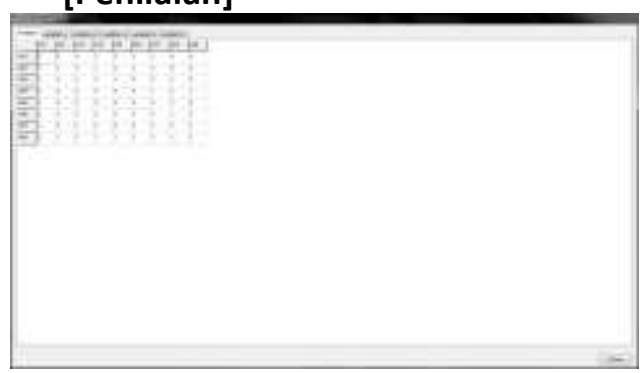

Gambar $\mathbf{5 . 5}$

Form Proses Metode Topsis

\subsection{Form Proses Metode Topsis}

[Langkah 1]

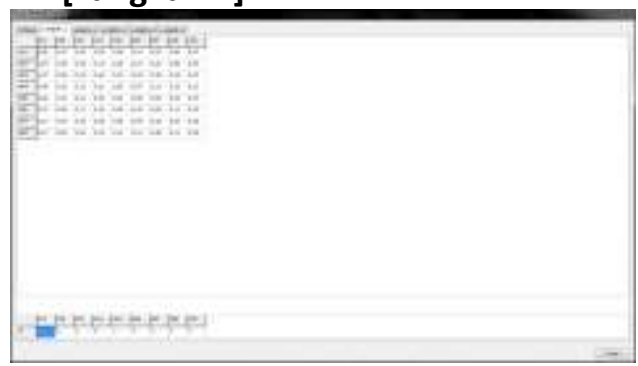

Gambar $\mathbf{5 . 6}$

Form Proses Metode Topsis Langkah 1 


\subsection{Form Proses Metode Topsis} [Langkah 2]

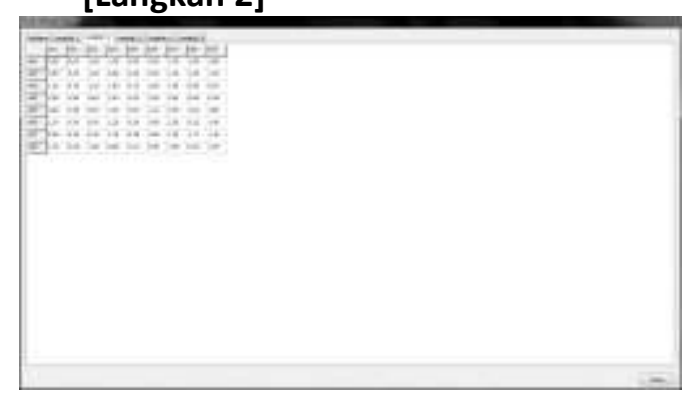

Gambar 5.7

Form Proses Metode Topsis Langkah 2

\subsection{Form Proses Metode Topsis} [Langkah 3]

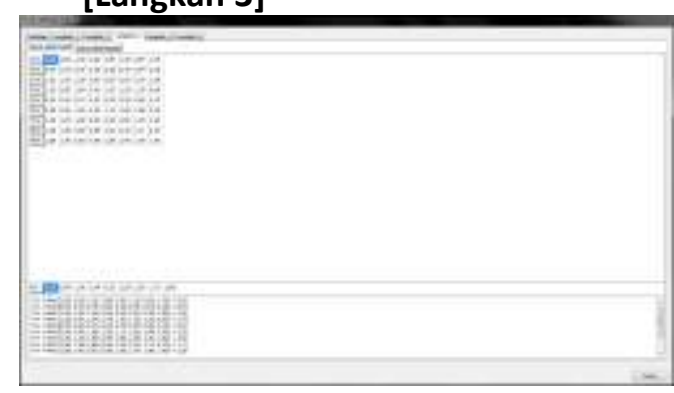

Gambar 5.8

Form Proses Metode Topsis Langkah 3

\subsection{Form Proses Metode Topsis [Langkah} 4]

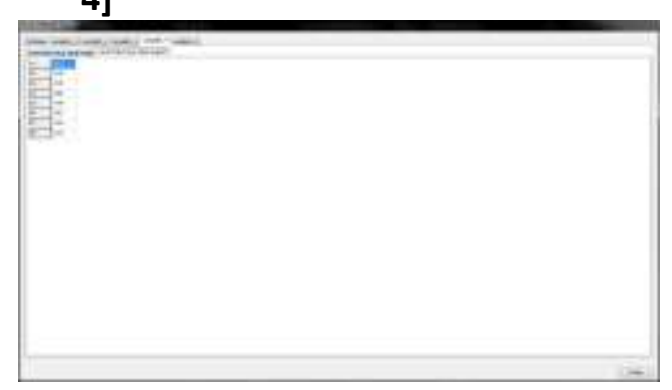

Gambar 5.9

Form Proses Metode Topsis Langkah 4

\subsection{Form Proses Metode Topsis [Langkah 5]}

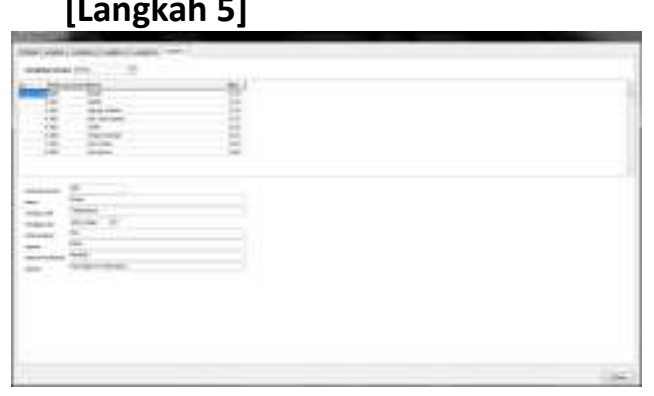

Gambar $\mathbf{5 . 1 0}$

Form Proses Metode Topsis Langkah 5

\section{KESIMPULAN}

1. Dapat memanipulasi data-data yang diperlukan sebagai bahan dalam proses pendukung keputusan penerimaan calon karyawan diantaranya adalah data calon karyawan, data kriteria penilaian, dan data penilaian;

2. Dapat melakukan dan menampilkan proses dalam bentuk langkah-langkah penyelesaian sesuai dengan metode topsis sampai dengan kesimpulan penilaian tiap calon karyawan beserta pilihan tampilan data kesimpulan sesuai dengan batasan rangking yang diinginkan;

3. Dapat menampilkan laporan datadata diantaranya laporan data calon karyawan, laporan data kriteria, laporan data penilaian;

4. Metode topsis adalah salah satu metode penentuan keputusan multi kriteria yang dapat digunakan dalam proses seleksi penerimaan calon karyawan untuk studi kasus di PT. Bank Mandiri Cabang Tasikmalaya;

5. Sistem ini hanya dapat digunakan oleh satu orang pengguna saja dan bersifat stand alone.

6. Diperlukan pengetahuan mengenai metode-metode apa saja yang dapat digunakan dan diterapkan dalam 
pembuatan sistem, khususnya yang berhubungan dengan proses sistem yang dibuat;

7. Masih diperlukan waktu yang lebih lama dan lebih detail untuk mengetahui teknis secara langsung dalam proses penerimaan calon karyawan khususnya di PT. Bank Mandiri Cabang Tasikmalaya ini;

8. Diperlukan pemahaman dan penggunaan metode lain sebagai bahan perbandingan dalam proses pembuatan sistem ini;

9. Untuk pengembangan lebih lanjutnya, aplikasi ini dapat digunakan dalam jaringan LAN;

10. Diperlukan adanya perbaikan dan pengembangan lebih baik lagi untuk penulisan laporan ataupun untuk implementasi dari sistem ini.

\section{DAFTAR PUSTAKA}

Fatansyah, Ir., Basis Data. Bandung : Informatika, 1999.

Ichwan, M., Pemograman Basis Data Delphi 7 dan MySql, Bandung, Informatika, 2011.

Inge Martine, Ir., Pemrograman Borland Delphi 6. Jakarta : PT ElexMedia Komputindo, 2004.

Jogiyanto HM. Analisis dan Disain Sistem Informasi : Pendekatan Terstruktur Teori dan Aplikasi bisnis. ANDI Offset, Yogyakarta. 2005.

Sri Kusumadewi, Artificial Intelligence, Graha IImu, Yogyakarta, 2003.

Nugroho, Bunafit. Database Relasional dengan MySQL. Andi Offset, Yogyakarta. 2004.
Sommerville, lan. Software Engineering (Rekayasa Perangkat Lunak)/Ian Sommerville; alih bahasa, Dra. Yuhilza Hanum, M.Eng, Edisi 6, Jilid 1. Erlangga, Jakarta. 2003.

Turban, Efraim, Aronson, Jay E., \& Liang, Ting-Peng. Decision Support and Intelligent Systems - 7th Ed. Jilid 1 (Sistem Pendukung Keputusan dan Sistem Cerdas), Diterjemahkan oleh: Dwi Prabantini. Andi Offset, Yogyakarta. 2005.

Handoko, T.Hani. Manajemen Sumber Daya Manusia. Yogyakarta : Penerbit PT. Bumi Aksara, 2001.

Hasibuan, Malayu . Manajemen Sumber Daya Manusia. Jakarta : Penerbit PT Bumi Aksara,2001. 